\title{
PENGARUH STRATEGI PEMBELAJARAN DAN MINAT BELAJAR TERHADAP KEMAMPUAN BERPIKIR KREATIF MATEMATIS SISWA
}

\author{
NURMA TAMBUNAN \\ nurma_tbn@yahoo.co.id \\ Program Studi Pendidikan Matematika, Fakultas Teknik, Matematika \& IPA \\ Universitas Indraprasta PGRI
}

\begin{abstract}
Abstrak. Tujuan umum dari penelitian ini adalah untuk menganalisis dan menguji kebenaran hipotesis mengenai pengaruh strategi pembelajaran dan minat belajar terhadap Kemampuan Berpikir Kreatif Matematis Siswa.Populasi terjangkau pada penelitian ini adalah siswa SMP Negeri Kota Depok Kls VIII tahun ajaran 2014/2015. Metode penelitian yang digunakan adalah eksperimen yang menggunakan desain ANAVA dua arah. Sampel berukuran 60 siswa yang terdiri dari 30 siswa kelas eksperimen dan 30 siswa kelas kontrol. Hasil penelitian menunjukkan bahwa: (1) Terdapat pengaruh yang signifikan strategi pembelajaran terhadap kemampuan berpikir kreatif matematis siswa, dibuktikan dengan nilai $F_{\text {hitung }} 13,626$ dan sig. 0,001 < 0,05 (2) Terdapat pengaruh yang signifikan minat belajar terhadap kemampuan berpikir kreatif matematis siswa, dibuktikan dengan nilai $F_{\text {hitung }} 15,992$ dan sig. 0,000 $<0,05$ (3) Terdapat pengaruh interaksi yang signifikan strategi pembelajaran dan minat belajar siswa terhadap kemampuan berpikir kreatif matematis siswa pada mata pelajaran matematika. Hal tersebut dibuktikan dengan nilai $F_{\text {-hitung }}(4,637)$ dan sig. $0,36(<0,05)$. Implikasinya seorang guru harus mempunyai banyak cara untuk meningkatkan kemampuan berpikir kreatif matematis siswa, dengan mempelajari berbagai strategi pembelajaran dan mengenal karakter siswa yang beragam. Strategi pembelajaran inkuiri dapat menjadi referensi dalam kegiatan pembelajaran.
\end{abstract}

Kata kunci: Strategi Pembelajaran, Minat Belajar, dan Kemampuan Berpikir Kreatif Matematis Siswa

\section{PENDAHULUAN}

Pendidikan adalah usaha sadar untuk menumbuh kembangkan potensi sumber daya manusia. pendidikan merupakan salah satu bidang yang mempunyai peranan besar dalam pembangunan di negara selain bidang ekonomi, politik, keamanan, dan sebagainya. Maju mundurnya bangsa ditentukan maju mundurnya pendidikan.Oleh karena itu, pendidikan harus dilaksanakan sebaik-baiknya agar memperoleh hasil yang maksimal.

Pendidikan menjadi tanggung jawab bersama, oleh karena itu perlu adanya kerja sama antara berbagai pihak seperti penentu kebijakan, pihak sekolah, orang tua, dan masyarakat luas. hal ini perlu disadari bahwa masalah yang dihadapi oleh dunia pendidikan di Indonesia pada saat ini adalah sangat beragam dan kompleks. salah satunya adalah krisis paradigma berupa kesenjangan dan ketidaksesuaian antara tujuan yang ingin dicapai dan paradigma yang digunakan. sebagai contoh dari kesenjangan ini, siswa pada setiap jenjang pendidikan di jejali dengan informasi yang harus di kuasai, sehingga siswa cenderung berusaha dengan pengetahuan jangka pendek, sementara di kehidupan di masa depan menuntut pemecahan persoalan yang inovatif dan kreatif.

Pelajaran matematika pada jenjang SMP untuk membekali siswa dengan kemampuan berpikir logis, analitis, sistematis, kritis, dan kreatif serta kemampuan bekerja sama. Kompetensi tersebut diperlukan peserta agar memiliki kemampuan 
memperoleh, mengolah, dan memanfaatkan informasi serta bertahan hidup pada keadaan yang selalu berubah, tidak pasti, dan kompetitif. Sedangkan standar kompetensi dan kompetensi dasar matematika disusun sebagai landasan untuk pembelajaran dalam mengembangkan kemampuan menggunakan matematika dalam pemecahan masalah dan mengkomunikasikan ide-ide atau gagasan dengan menggunakan simbol, tabel, diagram, dan media lain. Geometri adalah satu dari sekian banyak materi dalam matematika yang membutuhkan kreatifitas siswa.

Kemampuan berpikir kreatif sangat diperlukan manusia dalam menghadapi permasalahan didalam hidupnya, berpikir kreatif pada umumnya didapat dalam dunia pendidikan, karena dunia pendidikan adalah suatu hal yang paling penting dalam mengubah keadaan, dengan pendidikan kita mendapatkan ilmu, dengan ilmu kita dapat mengerti arti kehidupan baik kehidupan di dunia. Menurut Redja (2001: 30) pendidikan adalah segala pengalaman pendidikan yang baik harus memiliki tiga tujuan yaitu:

1. Memberikan kesempatan kepada semua orang untuk bebas mudah memperoleh sumber belajar setiap saat.

2. Memungkinkan semua orang yang ingin memberikan pengetahuan mereka kepada orang lain dengan mudah melakukannya, demikian pula bagi yang ingin mendapatkannya.

3. Menjamin tersedianya masukan umum yang berkenaan dengan pendidikan.

Pada pembelajaran matematika masih banyak siswa yang memperoleh hasil belajar yang kurang memenuhi harapan atau masih dibawah standar ketuntasan minimal yang seharusnya, hal ini diakibatkan karena masih kurangnya minat siswa dalam memahami konsep matematika untuk berpikir kreatif. Hal ini dapat terlihat dari kurang aktifnya siswa dalam proses pembelajaran, ini bisa terjadi karena guru masih banyak menggunakan strategi pembelajaran konvensional, seperti siswa hanya mendengarkan guru dalam menjelaskan materi, catat; siswa mencatat apa yang telah dijelaskan oleh guru, dan hapal; siswa diberi tugas oleh guru. Sehingga hal ini terkesan membosankan dan menyebabkan siswa kurang kreatif dalam pembelajaran matematika.

Salah satu faktor dominan adalah strategi dalam proses pembelajaran matematika, guru dalam mengelola proses kegiatan belajar mengajar di kelas masih terkesan monoton. Masih banyak kegiatan pembelajaran matematika yang menggunakan sistem duduk, dengar, catat dan hapal. Sehinggi siswa kurang antusias dan siswa kurang paham terhadap konsep matematika itu sendiri. Terkadang juga sikap guru yang hanya menerima cara menjawab soal latihannya sendiri yang dianggap benar, sedangkan ketika siswa menggunakan cara yang lain dianggap salah, sehingga membentuk persepsi negatif dari siswa terhadap bidang studi matematika dan menjadikan berpikir kreatif yang kurang. Proses yang berulang sering membuat siswa merasa tidak tertarik dan enggan untuk berkomentar karena merasa disalahkan, yang mengakibatkan siswa tidak dapat menyelesaikan persoalan matematika dalam kehidupannya sehari-hari.

Dalam kegiatan belajar, peran guru sangat penting di dalam menumbuhkan minat belajar siswa dan keberhasilan belajar siswa dapat ditentukan oleh minat belajar yang dimilikinya. Siswa yang memiliki minat belajar tinggi, cenderung prestasinya akan tinggi pula, sebaliknya siswa yang minat belajarnya rendah, akan rendah pula prestasi belajarnya. Minat (interest) berarti kecenderungan dan kegairahan yang tinggi atau keinginan yang besar terhadap sesuatu (Syah, 2010: 133). Minat belajar mempunyai pengaruh yang besar terhadap proses belajar siswa, jika materi yang dipelajari tidak sesuai dengan minat seorang siswa, maka ia tidak mempunyai rasa keinginan yang besar untuk memahami bahkan mendalami bahan pelajaran itu. Sehingga pada akhirnya siswa itu berprestasi kurang bagus. 
Hal ini disebabkan bahan pelajaran tidak mempunyai daya tarik baginya. Sebaliknya bahan pelajaran yang menarik minat siswa akan lebih mudah dipelajari dan diingat, karena dengan adanya minat peserta didik akan menambah giat belajar dan pada akhirnya akan berprestasi baik. Hal ini akan lebih baik kalau didukung dengan kreatifitas yang tinggi.Dalam mengantisipasi masalah diatas, guru dituntut untuk mencari dan menemukan suatu cara yang menumbuhkan minat sekaligus pemikiran kreatif dalam belajar yang dilakukan oleh siswa

Dari beberapa strategi pembelajaran yang ada dengan memperhatikan karakteristik siswa serta permasalahan yang ada, peneliti memilih strategi pembelajaran inkuiri untuk diujicobakan dalam penelitian ini. Karena dengan strategi pembelajaran ini, siswa lebih aktif membangun pengalamannya sendiri.Mengingat masih banyak siswa yang hasil belajar matematikanya kurang memuaskan disebabkan kurangnya minat dan strategi pembelajaran yang kurang tepat digunakan kepada siswa dalam proses pembelajaran di kelas, maka peneliti akan melakukan eksperimen yang dituangkan dalam artikel berjudul "Pengaruh Strategi Pembelajaran dan Minat Belajar Siswa terhadap Kemampuan berpikir Kreatif Matematis Siswa"(Eksperimen pada Siswa Kelas VIII SMP Negeri Kota Depok)

\section{TINJAUAN PUSTAKA}

\section{Hakikat Kemampuan Berpikir Kreatif}

Berpikir kreatif sesungguhnya adalah suatu kemampuan berpikir yang berawal dari adanya kepekaan terhadap situasi yang sedang dihadapi, misalnya situasi itu terdeteksi atau teridentifikasi adanya masalah yang ingin atau harus diselesaikan. Hasil yang dimunculkan dari berpikir kreatif itu sesungguhnya merupakan suatu yang baru bagi yang bersangkutan serta merupakan suatu yang berbeda dari yang biasanya dia lakukan.

Kreatifitas seringkali diartikan sebagai melihat atau mengekspresikan sesuatu hubungan baru sehingga kreativitas dapat ditemukan dalam proses berpikir, interaksi sosial, pembelajaran, pekerjaan bahkan bermain sekalipun. Apapun yang kita lakukan, dengan membuat sesuatu yang baru ataupun menambah sentuhan baru maka kreatifitas dapat muncul tanpa kita sadari (Rochyani, 2004: 8).Kreatifitas ini merupakan salah satu bentuk kecerdasan intelektual atau yang lebih sering dikenal dengan Intelegent Quotient ( IQ ).

Hilgard dalam Uno (2014: 113) berpikir kreatif adalah sebagai suatu bentuk pemikiran, berusaha menemukan hubungan-hubungan baru, mendapatkan jawaban, metode atau cara-cara baru dalam menanggapi suatu masalah, atau menghasilkan bentukbentuk artistik baru. Sejalan dengan itu Schwartz mendefenisikan berpikir kreatif adalah menemukan cara baru yang lebih baik untuk mengerjakan segala sesuatu.

Menurut Surya (2011:191) berpikir kreatif akan memudahkan seseorang dalam mengembangkan proses berpikir, menunjukkan keberanian mencari, memunculkan dan menemukan ide-ide baru maupun berbagai alternatif untuk menghadapi dan memecahkan tantangan hidup maupun keinginan menciptakan hal-hal baru yang orisinal

Ciri-ciri kreatifitas dapat dibedakan ke dalam ciri kognitif dan non kognitif. Ciri kognitif meliputi fluency (kelancaran), flexibility (keluwesan), originality (keaslian), elaboration (penguraian) dan ciri-ciri non kognitif meliputi minat atau motivasi, sikap, dan kepribadian. Keduanya sangatlah penting dan saling menunjang.

Dari beberapa definisi di atas dapat disimpulkan bahwa berpikir kreatif adalah kemampuan seseorang dalam mengungkapkan ide-ide atau gagasan yang ada pada dirinya guna memecahkan masalah yang dihadapinya baik secara konsep maupun nyata, sehingga menghasilkan ide-ide baru atau cara memandang seseuatu dengan cara yang berbeda dari biasanya. 


\section{Hakikat Strategi Pembelajaran}

Dalam dunia pendidikan, strategi pembelajaran adalah perencanaan yang berisi tentang rangkaian kegiatan yang didesain untuk mencapai tujuan pendidikan.Upaya mengimplementasikan rencana yang sudah disusun dalam kegiatan nyata agar tujuan yang telah disusun tercapai optimal disebut strategi.

Kemp 1995 (Sanjaya, 2011: 294), menjelaskan bahwa strategi pembelajaran adalah kegiatan pembelajaran yang harus dikerjakan guru dan siswa agar tujuan pembelajaran dapat dicapai secara efektif dan efisien. Indrawati menyatakan bahwa suatu pembelajaranpada umumnya akan lebih efektif bila diselenggaran melalui strategi-strategi pembelajaran yang termasuk rumpun pemrosesan informasi.

Wiryam dan Noorhadi (1990) dalam Uno (2014) mengatakan bahwa strategi pembelajaran merupakan pemilihan atas berbagai jenis latihan yang sesuai dengan tujuan pembelajaran yang ingin dicapai.Ia menegaskan bahwa setiap tingkah laku yang diharapkan dapat dicapai oleh peserta didik dalam kegiatan belajar harus dipraktikkan.

Lebih lanjut dalam Kurikulum Sekolah Menengah Umum, Departemen Pendidikan Nasioanal (Depdiknas) memberikan batasan prinsip pembelajaran diantaranya meliputi: bagaimana pengolahan strategi pembelajaran, metode pembelajaran, struktur pembelajaran, pengelolaan kelas dan laboratorium, penggunaan teknik bertanya dan penilaian hasil belajar.

Dari beberapa pendapat di atas, dapat disimpulkan bahwa strategi pembelajaran adalah rencana dan cara-cara membawakan pengajaran agar segala prinsip dasar dapat terlaksana dan segala tujuan pengajaran dapat dicapai secara efektif. Strategi pembelajaran yang dipilih oleh guru akan berpengaruh besar terhadap tingkat ketercapaian tujuan pembelajaranyaitu kemampuan berpikir kreatif matematis. Pemilihan strategipembelajaran yang tepat akan memotivasi siswa untuk gairah dalam belajar.

\section{Strategi Pembelajaran Inkuiri}

Strategi pembelajaran inkuiri dipengaruhi oleh aliran belajar kognitif. Menurut aliran ini belajar pada hakikatnya adalah proses mental dan proses berpikir dengan memanfaatkan segala potensi yang dimiliki setiap individu secara optimal. Belajar lebih dari sekedar proses menghafal dan menumpuk ilmu pengetahuan, tapi bagaimana pengetahuan yang diperolehnya bermakna untuk siswa melalui keterampilan berpikir.

Menurut Sanjaya (2011: 303) "strategi pembelajaran inkuiriadalah rangkaian pembelajaran yang menekankan pada proses berpikir secara kritis dan analitis untuk mencari dan menemukan sendiri jawaban yang sudah pasti dari suatu masalah yang dipertanyakan". Proses berpikir itu sendiri biasanya dilakukan melalui tanya jawab antara guru dan siswa.

Menurut Nurhadi dan Agus, Gerrad, S (2003: 71),"Dalam pembelajaran dengan penemuan/inkuiri, siswa didorong untuk belajar sebagian besar melalui keterlibatan aktif mereka sendiri dengan konsep-konsep dan prinsip-prinsip dan guru mendorong siswa untuk memiliki pengalaman dan melakukan percobaan yang memungkinkan mereka menemukan prinsip-prinsip untuk diri mereka sendiri”.

Dari beberapa pendapat diatas dapat disimpulkan bahwa strategi pembelajaran inkuiri dapat disimpulkan sebagai strategi yang menekankan pengetahuan yang dicari dan ditemukan sendiri oleh siswa dengan konsep-konsep dan prinsip-prinsip yang dimiliki oleh siswa itu sendiri. Guru mendorong siswa untuk memiliki pengalaman dan melakukan percobaan yang memungkinkan mereka menemukan prinsip-prinsip untuk mereka sendiri. 


\section{Strategi Pembelajaran Ekspositori}

Strategi ekspositori atau kuliah (lecture method) adalah sebuah cara melaksanakan pembelajaran yang dilakukan siswa secara monolog dan hubungan satu arah (one way communication). Menurut Syah (2010), ekspositori ialah sebuah model mengajar dengan menyampaikan informasi dan pengetahuan secara lisan kepada sejumlah siswa yang pada umumnya mengikuti secara pasif. Hal ini sejalan dengan hasil penelitian Ross dan Kyle 1987 (Sanjaya, 2011: 180) "strategi ini sangat efektif untuk mengajarkan konsep dan keterampilan untuk anak-anak yang memiliki kemampuan kurang".

Aktifitas siswa dalam pembelajaran yang menggunakan strategi ini hanya menyimak sambil sesekali mencatat. Meskipun begitu, para guru yang terbuka terkadang memberi peluang bertanya kepada sebagian kecil siswanya. Strategi ekspositori dapat dikatakan sebagai satu-satunya strategi yang paling ekonomis untuk menyampaikan informasi. Di samping itu, model ini juga paling efektif dalam mengatasi kelangkaan literatur atau rujukan yang sesuai dengan jangkauan daya beli dan daya paham siswa.

Dari beberapa pendapat di atas dapat disimpulkan bahwa strategi pembelajaran ekspositori adalah strategi yang menekankan pengetahuan yang berpusat kepada guru, siswa hanya mencatat dan menghapalkan konsep-konsep yang dijelaskan baik oleh guru maupun siswa. Pada strategi eskpositori guru berfungsi sebagai penyampai informasi yang memberikan materi pembelajaran begitu saja pada siswa dan siswa tidak dituntut untuk mengolahnya dan kewajiban siswa hanya untuk menguasai materi sepenuhnya.

\section{Hakikat Minat belajar Siswa}

Minat merupakan salah satu faktor yang dapat mempengaruhi usaha yang dilakukan seseorang. Minat yang kuat akan menimbulkan usaha yang gigih dan serius serta tidak mudah putus asa dalam menghadapi tantangan. Jika seorang siswa memiliki rasa ingin belajar, ia akan cepat mengertia dan mengingat apa yang sudah dipelajariMinat belajar siswa adalah keinginan siswa untuk menekuni kegemarannya dalam suatu mata pelajaran.

Menurut beberapa ahli pendidikan dalam Slameto (2013: 180) berpendapat bahwa cara yang paling efektif untuk membangkitkan minat pada suatu subyek yang baru adalah dengan menggunakan minat-minat siswa yang telah ada. Misalnya siswa menaruh minat dalam menggambar, maka sebelum mengajarkan materi bangun ruang, guru dapat menarik perhatian siswa dengan sedikit dengan gambar-gambar yang telah ditampilkan, kemudian sedikit demi sedikit diarahkan ke materi pelajaran yang sesungguhnya.

Nasution (2008: 46) bahwa ketekunan belajar ini bertalian dengan sikap dan minat terhadap pelajaran. Bila suatu pelajaran tidak menarik minat seseorang karena suatu hal, maka ia segera menyampingkannya jika menemukan kesulitan. Sebaliknya, jika suatu tugas menarik karena memberikan hasil yang menggembirakan, ia cenderung untuk memberikan waktu yang lebih banyak untuk tugas itu.

Menurut Bernard (Sardiman, 2004: 76) minat timbul tidak secara tiba-tiba/ spontan melainkan timbul dari partisipasi, pengalaman, kebiasaan pada waktu belajar atau bekerja. Jadi jelas soal minat akan selalu berkaitan dengan kebutuhan atau keinginan, oleh karena itu yang penting bagaimana menciptakan kondisi tertentu agar siswa itu selalu butuh dan ingin terus belajar.

Dari berbagai uraian di atas dapat disimpulkan bahwa minat belajar adalah sesuatu rasa ketertarikan pada suatu hal atau aktifitas belajar seseorang. Minat pada dasarnya adalah penerimaan akan sesuatu hubungan antara diri sendiri dengan sesuatu di luar diri. Semakin kuat atau dekat hubungan tersebut, semakin besar minatnya.

\section{Minat Belajar Tinggi}


Jika seseorang menaruh perhatian terhadap sesuatu, maka minat akan menjadi motivasi yang kuat untuk berhubungan secara lebih aktif dengan sesuat yang menarik minatnya. Minat akan semakin bertambah jika disalurkan dalam suatu kegiatan. Keterikatan dengan kegiatan tersebut akan menumbuhkembangkan minat.

Menurut Syah (2010:136) minat tinggi atau besar apabila seorang siswa akan memusatkan perhatiannya lebih banyak dari siswa lainnya sehingga siswa tersebut untuk belajar lebih giat dan akhirnya mencapai prestasi yang diinginkan.Kemudian menurut Dakir dalam Tinik (2011:46) untuk mencapai prestasi yang baik disamping kecerdasan juga minat.Sebab tanpa adanya minat segala kegiatan yang dilakukan kurang efektif dan efisien.Dalam kehidupan sehari-hari seringkali kita dikecohkan dengan pengertian perhatian dengan minat, dalam pelaksanaannya perhatian seolah-olah kita menonjolkan fungsi pikiran dan minat menonjolkan fungsi rasa. Tetapi pada kenyataannya apa yang menarik minat menyebabkan perhatian yang menarik.

Dari beberapa pendapat diatas dapat disimpulkan bahwa minat belajar tinggi adalah keinginan atau suatu kecenderungan yang ada dalam diri siswa untuk melakukan suatu secara maksimal atau optimal karena adanya perasaan senang terhadap materi pembelajaran yang dipelajarinya secara tanggung jawab dan konsekuen.Siswa yang memiliki Minat belajar tinggi akan cenderung tekun, ulet, semangat dalam belajar, pantang menyerah dan senang menghadapi tantangan. Mereka memandang setiap hambatan belajar sebagai tantangan yang harus mampu diatasi.

\section{Minat Belajar Rendah}

Seorang yang memiliki minat rendah tidak ada ketertarikan terhadap suatu objek.Siswa yang memiliki tingkat minat belajar belajar fisika rendah, umumnya akan malas belajar, cenderung menghindar dari tugas dan pekerjaan yang berbau fisika. Akan merasa senang jika guru fisika tidak hadir, dan tidak ada upaya untuk belajar mandiri menambah pengetahuan baik melalui bertanya pada teman maupun membaca literatur. Jika ada tugas pekerjaan rumah atau tugas lainnya dikerjakan hanya sekedar untuk memenuhi dan menggugurkan kewajiban saja, tidak mempedulikan bahwa tugas tersebut bermakna atau tidak.

Siswa yang memiliki minat belajar rendah dibutuhkan peranan guru yang tinggi dalam menyemangati belajar. Proses pembelajaran matematikaharus memperhatikan strategi pembelajaran yang digunakan dan diduga strategi inkuiri diduga tepat bagi siswa yang berminat belajar rendah.

\section{METODE}

Metode yang digunakan dalam penelitian adalah metode eksperimen, yaitu dengan mengadakan serangkaian perlakuan secara langsung terhadap sampel. Hal tersebut didasarkan pada konsep Arikunto (2002:272) "tujuan penelitian eksperimen menyelidiki kemungkinan saling hubungan sebab akibat dengan cara menggunakan satu atau lebih kelompok eksperimen satu atau lebih kondisi perlakuan dan membandingkan hasilnya dengan satu atau lebih kelompok kontrol yang tidak dikenai kondisi perlakuan". Selanjutnya untuk mengetahui ada tidaknya pengaruh hasil eksperimen berupa perlakuan strategi pembelajaran yaitu strategi pembelajaran inkuiri dan srategi pembelajaran ekspositori, maka peneliti mengadakan tes atau evaluasi terhadap kemampuan berpikir kreatif matematis siswa pada masing-masing kelas sampel setelah eksperimen dilakukan.

Untuk mendapatkan sejumlah data yang diperlukan sehubungan dengan masalah penelitian, maka peneliti mengadakan serangkaian pembelajaran dengan materi "bangun ruang sisi datar". Subjek penelitian dibagi atas dua kelompok yakni kelompok eksperimen dengan strategi pembelajaran inkuiri dan kelompok kontrol dengan strategi 
pembelajaran ekspositori. Kedua Kelompok diberi perlakuan khusus yaitu diberi angket tentang minat belajar yang selanjutnya dibagi dua kelompok yang berminat tinggi dan yang berminat rendah. Perlakuan yang diberikan bertujuan untuk mengetahui apakah terdapat perbedaan antara kedua strategi pembelajaran yang diterapkan dalam hal memacu kemampuan berpikir kreatif matematis siswa. Desain yang digunakan dalam penelitian ini adalah desain faktorial $2 \times 2$. Desain eksperimen ini dapat digambarkan seperti tabel berikut:

\begin{tabular}{|c|c|c|c|}
\hline Minat belajar & $\begin{array}{l}\text { 这 } \\
: \Xi \\
: \frac{3}{\Xi}\end{array}$ & 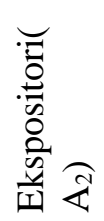 & $\frac{\bar{\Xi}}{\Xi}$ \\
\hline Tinggi $\left(\mathrm{B}_{1}\right)$ & $\mathrm{A}_{1} \mathrm{~B}_{1}$ & $\mathrm{~A}_{2} \mathrm{~B}_{1}$ & $\mathrm{~B}_{1}$ \\
\hline Rendah $\left(B_{2}\right)$ & $\mathrm{A}_{1} \mathrm{~B}_{2}$ & $\mathrm{~A}_{2} \mathrm{~B}_{2}$ & $\mathrm{~B}_{2}$ \\
\hline Jumlah & $\mathrm{A}_{1}$ & $\mathrm{~A}_{2}$ & $\mathrm{~A} \times \mathrm{B}$ \\
\hline
\end{tabular}

Gambar 1. Desain Penelitian

Keterangan:

A1 : kelompok siswa dengan strategi pembelajaran inkuiri.

A2 : kelompok siswa dengan strategi pembelajaran ekspositori.

B1 : kelompok siswa dengan minat belajar tinggi.

B2 : kelompok siswa dengan minat belajar rendah.

$\mathrm{A}_{1} \mathrm{~B}_{1}$ : kemampuan berpikir kreatif matematis siswa yang mempunyai minat belajar tinggipada mata pelajaran matematika dengan strategi pembelajaran inkuiri.

$\mathrm{A}_{2} \mathrm{~B}_{1}$ : kemampuan berpikir kreatif matematis siswa yang mempunyai minat belajar tinggi pada mata pelajaran matematika dengan strategi pembelajaran ekspositori.

$\mathrm{A}_{1} \mathrm{~B}_{2}$ : kemampuan berpikir kreatif matematis siswa yang mempunyai minat belajar rendah pada mata pelajaran matematika dengan strategi pembelajaran inkuiri.

$\mathrm{A}_{2} \mathrm{~B}_{2}$ : kemampuan berpikir kreatif matematis siswa yang mempunyai minat belajar rendah pada mata pelajaran matematika dengan strategi pembelajaran ekspositori.

\section{HASIL DAN PEMBAHASAN}

\section{Hasil Penelitian}

Dalam Penelitian ini data di analisis dengan menggunakan ANAVA dua arah dengan hasil sebagai berikut:

Tests of Between-Subjects Effects

Tabel 1. Hasil Uji Hipotesis Penelitian

Dependent Variable: Y

\begin{tabular}{|l|l|l|l|l|l|}
\hline Source & $\begin{array}{l}\text { Type III Sum } \\
\text { of Squares }\end{array}$ & Df & Mean Square & F & Sig. \\
\hline Corrected Model & $1182.533^{\mathrm{a}}$ & 3 & 394.178 & 11.418 & .000 \\
Intercept & 416000.267 & 1 & 416000.267 & 12050.494 & .000 \\
FAKTOR1 & 470.400 & 1 & 470.400 & 13.626 & .001 \\
FAKTOR2 & 552.067 & 1 & 552.067 & 15.992 & .000 \\
FAKTOR1 & 160.067 & 1 & 160.067 & 4.637 & .036 \\
FAKTOR2 & & & & &
\end{tabular}




\begin{tabular}{|l|l|l|l|l|l|} 
Error & 1933.200 & 56 & 34.521 & & \\
Total & 419116.000 & 60 & & & \\
Corrected Total & 3115.733 & 59 & & & \\
\hline
\end{tabular}

a. R Squared $=.380$ (Adjusted R Squared $=.346$ )

Berdasarkan hasil perhitungan di atas dapat diketahui bahwa:

1. Pengaruh strategi pembelajaran terhadap kemampuan berpikir kreatif matematis memiliki nilai $F_{\text {hitung }}$ sebesar 13,626 dengan sig.0,001 $<0,05$. sehingga dapat disimpulkan bahwa terdapat pengaruh strategi pembelajaran terhadap kemampuan berpikir kreatif matematis siswa.

2. Pengaruh minat belajar terhadap kemampuan berpikir kreatif matematis memiliki

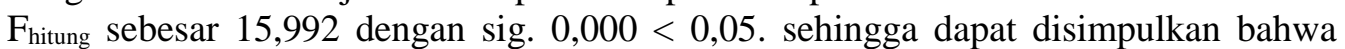
terdapat pengaruh minat belajar terhadap kemampuan berpikir kreatif matematis siswa.

3. Pengaruh interaksi strategi pembelajaran dan minat belajar terhadap kemampuan berpikir kreatif matematismemiliki nilai $\mathrm{F}_{\text {hitungsebesar4,637 dengan sig. } 0,04<0,05 \text {. hal }}$ ini menjunjukkan bahwa terdapat pengaruh interaksi antara strategi pembelajaran dan minat belajar terhadap kemampuan berpikir kreatif matematis siswa.

Dengan demikian dilakukan uji lanjut dengan uji t sebagai berikut:

Tabel 2. Ringkasan Hasil Uji Tukey

DepenSdent Variable: Y

Tukey HSD

\begin{tabular}{|cc|c|c|c|c|c|}
\hline (I) PH (J) PH & $\begin{array}{c}\text { Mean Difference } \\
(\mathrm{I}-\mathrm{J})\end{array}$ & Std. Error & Sig. & \multicolumn{2}{|c|}{ 95\% Confidence Interval } \\
\cline { 5 - 6 } & & & & LowerBound & Upper Bound \\
\hline & $\mathrm{A}_{1} \mathrm{~B}_{2}$ & $9.3333^{*}$ & 2.14543 & .000 & 3.6525 & 15.0142 \\
$\mathrm{~A}_{1} \mathrm{~B}_{1}$ & $\mathrm{~A}_{2} \mathrm{~B}_{1}$ & $8.8667^{*}$ & 2.14543 & .001 & 3.1858 & 14.5475 \\
& $\mathrm{~A}_{2} \mathrm{~B}_{2}$ & $11.6667^{*}$ & 2.14543 & .000 & 5.9858 & 17.3475 \\
& $\mathrm{~A}_{1} \mathrm{~B}_{1}$ & $-9.3333^{*}$ & 2.14543 & .000 & -15.0142 & -3.6525 \\
$\mathrm{~A}_{1} \mathrm{~B}_{2}$ & $\mathrm{~A}_{2} \mathrm{~B}_{1}$ & -.4667 & 2.14543 & .996 & -6.1475 & 5.2142 \\
& $\mathrm{~A}_{2} \mathrm{~B}_{2}$ & 2.3333 & 2.14543 & .699 & -3.3475 & 8.0142 \\
& $\mathrm{~A}_{1} \mathrm{~B}_{1}$ & $-8.8667^{*}$ & 2.14543 & .001 & -14.5475 & -3.1858 \\
$\mathrm{~A}_{2} \mathrm{~B}_{1}$ & $\mathrm{~A}_{1} \mathrm{~B}_{2}$ & .4667 & 2.14543 & .996 & -5.2142 & 6.1475 \\
& $\mathrm{~A}_{2} \mathrm{~B}_{2}$ & 2.8000 & 2.14543 & .564 & -2.8808 & 8.4808 \\
& $\mathrm{~A}_{1} \mathrm{~B}_{1}$ & $-11.6667^{*}$ & 2.14543 & .000 & -17.3475 & -5.9858 \\
$\mathrm{~A}_{2} \mathrm{~B}_{2}$ & $\mathrm{~A}_{1} \mathrm{~B}_{2}$ & -2.3333 & 2.14543 & .699 & -8.0142 & 3.3475 \\
& $\mathrm{~A}_{2} \mathrm{~B}_{1}$ & -2.8000 & 2.14543 & .564 & -8.4808 & 2.8808 \\
\hline
\end{tabular}

Based on observed means.

The error term is Mean Square(Error) $=34.521$.

*. The mean difference is significant at the 0.05 level.

Berdasarkan uji lanjut pada tabel 2 di atas dapat disimpulkan sebagai berikut:

1. Kemampuan bepikir kreatif matematis siswa yang memiliki minat belajar tinggi lebih baik secara signifikan dibandingkan dengan siswa yang memiliki minat belajar rendah khusus pada siswa yang diajar dengan strategi pembelajaran inkuiri. hal ini disebabkan selisih antara kelompok $A_{1} B_{1}$ dan $A_{1} B_{2}$ adalah 9,3333; yang artinya kelompok $A_{1} B_{1}$ lebih tinggi dibandingkan dengan kelompok $\mathrm{A}_{1} \mathrm{~B}_{2}$ dan dapat dibuktikan dengan nilai sig $0,000<0,05$. 
2. Terdapat perbedaan kemampuan berpikir kreatif matematis siswa yang diajar menggunakan strategi pembelajaran inkuiri dan strategi pembelajaran ekspositori, atau lebih jauh dikatakan bahwa kemampuan bepikir kreatif matematis siswa yang diajar dengan menggunakan strategi pembelajaran inkuiri lebih tinggi secara signifikan dibandingkan dengan siswa yang diajar menggunakan strategi pembelajaran ekpositori khususnya pada siswa yang memiliki minat belajar tinggi. ini terlihat bahwa selisih antara kelompok $A_{1} B_{1}$ dan $A_{2} B_{1}$ adalah 8,8667; yang artinya kelompok $A_{2} B_{1}$ lebih rendah dibandingkan dengan kelompok $\mathrm{A}_{1} \mathrm{~B}_{1}$ dan dapat dibuktikan dengan nilai sig $0,001<0,05$.

3. Tidak terdapat perbedaan signifikan kemampuan berpikir kreatif matematis siswa yang diajar menggunakan strategi pembelajaran inkuiri dengan siswa yang diajar menggunakan strategi pembelajaran ekspositori, khususnya pada siswa yang memiliki minat belajar rendah. ini terlihat bahwa selisih antara kelompok $A_{1} B_{1}$ dan $A_{2} B_{2}$ adalah 2,3333; yang artinya kelompok $\mathrm{A}_{2} \mathrm{~B}_{2}$ lebih tinggi dibandingkan dengan kelompok $\mathrm{A}_{1} \mathrm{~B}_{2}$ dan dapat dibuktikan dengan nilai sig $0,699>0,05$

4. Tidak terdapat perbedaan yang signifikan kemampuan berpikir kreatif matematis siswa yang memiliki minat belajar tinggi dengan siswa yang memiliki minat belajar rendah khususnya pada siswa yang diajar dengan strategi pembelajaran ekspositori. ini terlihat bahwa selisih antara kelompok $\mathrm{A}_{2} \mathrm{~B}_{1}$ dan $\mathrm{A}_{2} \mathrm{~B}_{2}$ adalah 2,8000; yang artinya kelompok $\mathrm{A}_{2} \mathrm{~B}_{2}$ lebih tinggi dibandingkan dengan kelompok $\mathrm{A}_{2} \mathrm{~B}_{1}$ dan dapat dibuktikan dengan nilai sig $0,564>0,05$.

\section{Pembahasan}

Berdasarkan hasil penelitian dapat diketahui bahwa kemampuan berpikir kreatif matematis siswa dapat dipengaruhi oleh strategi pembelajaran dan minat belajar siswa. Secara rinci berdasarkan temuan penelitian dan hasil pengujian hipotesis sebagai berikut:

\section{Pengaruh Strategi Pembelajaran terhadap Kemampuan Berpikir Kreatif Matematis Siswa}

Pada penelitian ini diperoleh bahwa kemampuan berpikir kreatif matematis siswa yang menggunakan strategi pembelajaran inkuiri lebih tinggi dari pada siswa yang menggunakan strategi pembelajaran ekspositori.Kesimpulan ini didukung oleh perolehan statistik deskriptif yang menunjukkan rerata kemampuan berpikir kreatif matematis siswa yang menggunakan strategi pembelajaran inkuiri sebesar 86,067 sedangkan rerata kemampuan berpikir kreatif matematik siswa yang menggunakan strategi pembelajaran ekspositori sebesar 80,467.Perbedaan ini juga diperkuat dengan hasil Anova yang memperlihatkan nilai sig $0,001<0,05$, dengan harga $F_{\text {hitung }}$ sebesar 13.626 Ini berarti $\mathrm{H}_{0}$ ditolak. Hasil ini memperkuat asumsi bahwa strategi pembelajaran yang berbeda akan memberikan kemampuan berpikir kreatif matematik siswa terhadap mata pelajaran matematika yang berbeda pula.

Menurut sintesis teori yang ada di Bab II, strategi pembelajaran adalah rencana dan cara-cara membawakan pengajaran agar segala prinsip dasar dapat terlaksana dan segala tujuan pengajaran dapat dicapai secara efektif. Strategi pembelajaran yang dipilih oleh guru akan berpengaruh besar terhadap tingkat ketercapaian tujuan pembelajarandalam hal ini kemampuan berpikir kreatif matematik siswa.Pemilihan strategipembelajaran yang tepat akan memotivasi siswa untuk gairah dalam belajar, sehingga siswa dapat melakukan yang dapat menciptakan kemampuan keatifitas. Strategi pembelajaran yang baik adalah bagaimana siswa memahami dan mengajak siswa untuk berpikir kreatif.

Sedangkan kemampuan berpikir kreatif matematis siswa adalah kemampuan siswa dalam mengungkapkan ide-ide atau gagasan yang ada pada dirinya guna 
memecahkan soal-soal atau permasalahan matematika yang sedang dihadapinya, serta mampu menyelesaikannya dari sudut pandang yang berbeda dari biasanya.Kemampuan menemukan banyak kemungkinan jawaban terhadap suatu masalah yang didasari data atau informasi yang tersedia, yang penekanannya pada kuantitas yang memenuhi lima unsur berpikir kreatif sebagai berikut: (a) Berpikir Lancar (fluency) adalah merupakan kemampuan untuk mencetuskan banyak gagasan, jawaban dan memikirkan lebih dari satu jawaban.(b) Berpikir Luwes (Flexibility) adalah kemampuan untuk menghasilkan ide-ide yang beragam, sudut pandang yang berbeda dan mampu mengubah pendekatan.(c) Berpikir Orisinil (Originality) adalah kemampuan untuk melahirkan ungkapan yang baru dan unik, ide yang tak lazim diantara kebanyakan atau jarang. (d) Berpikir Elaboratif (Elaboration) adalah kemampuan untuk memperkaya dan mengembangkan suatu gagasan atau mampu menambah dan merinci detail dari suatu gagasan sehingga menjadi lebih menarik. (e) Berpikir Evaluatif (Evaluatif) adalah kemampuan untuk menentukan patokan penilaian sendiri dan menentukan apakah suatu pernyataan benar, suatu rencana sehat, suatu tindakan bijaksana dan mampu mengambil keputusan untuk situasi yang terbuka.

Dari informasi kuantitatif dan teori tersebut dapat disimpulkan bahwa kemampuan berpikir kreatif matematis siswa pada mata pelajaran matematika dipengaruhi oleh strategi pembelajaran.

\section{Pengaruh Minat Belajar terhadap Kemampuan Berpikir Kreatif Matematis} Siswa

Penelitian ini berhasil menemukan bahwa kemampuan berpikir kreatif matematis siswa yang memiliki minat tinggi lebih tinggi daripada siswa yang memiliki minat belajar rendah.Kesimpulan ini didukung oleh perolehan statistik deskriptif yang menunjukkan perbedaan antara rerata kemampuan berpikir kreatif dengan siswa pada minat belajar tinggi sebesar 86.3 dan siswa dengan minat belajar rendah sebesar 80.2. sehingga pengaruh minat belajar terhadap kemampuan berpikir kreatif matematis didapat hasil $\mathrm{F}_{0}=15,992$ dengannilai sig $0,000<0,05$, berarti $\mathrm{H}_{0}$ ditolak.

Fenomena ini menunjukkan bahwa kemampuan berpikir kreatifmatematis siswa akan meningkat jika siswa memiliki minat terhadap mata pelajaran matematika. Dalam arti bahwa kemampuan berpikir kreatif adalah erubahan pola tingkah laku yang menuju kearah yang berkualitas sangat dipengaruhi oleh faktor internal (misalnya kecerdasan, minat, kognitif) dan faktor eksternal yang terdapat pada lingkungannya (misalnya guru, kurikulum, strategi pembelajaran).

Menurut sintesis teori yang ada di Bab II, minat belajar belajar adalah sesuatu rasa ketertarikan pada suatu hal atau aktifitas belajar seseorang. Minat pada dasarnya adalah penerimaan akan sesuatu hubungan antara diri sendiri dengan sesuatu di luar diri. Semakin kuat atau dekat hubungan tersebut, semakin besar minatnya.Secara operasional minat belajar adalah sesuatu rasa ketertarikan pada suatu hal atau aktifitas belajar seorang siswa yang secara langsung mempengaruhi prilaku belajar siswa. Tercapainya tujuan kegiatan proses pembelajaran faktor minat belajar yang tinggi sangat diperlukan., semakin tinggi keinginan untuk mencapai tujuan akan semakin kuat pulan minat yang mendorong. Sesuai dengan kondisi tersebut kiranya guru dan orang tua memberi harapan pada anak dalam membangun cita-cita yang mampu mendukung lahirnya minat belajar. 
Dari informasi kuantitatif dan teori tersebut dapat disimpulkan bahwa kemampuan berpikir kreatif matematis siswa dalam mengikuti kegiatan pembelajaran sangat dipengaruhi oleh minat belajar siswa.

\section{Pengaruh Interaksi Strategi Pembelajaran dan Minat Belajar terhadap Kemampuan Berpikir Kreatif Matematis Siswa}

Pada penelitian ini, terdapat interaksi antara antara strategi pembelajaran dan minat belajar terhadap kemampuan berpikir kreatif matematik siswa pada mata pelajaran matematika. Hal ini terlihat dari hasil ANAVA, yaitu harga F-hitung

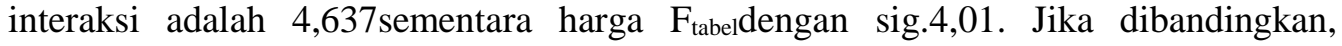
terlihat bahwa harga F-hitung interaksi lebih dari harga F-tabel pada taraf signifikansi $5 \%$. Begitu juga untuk output SPSS, terlihat bahwa sign. untuk interaksi sebesar 0,04 $<0,05$. Ini berarti bahwa hipotesis nol yang diajukan dalam penelitian ini ditolak dan menerima hipotesis alternatif.Penelitian ini berhasil menemukan bahwa kemampuan berpikir kreatif matematik siswa yang menggunakan strategi pembelajaran Inkuiri lebih tinggi dari pada siswa yang menggunakan strategi pembelajaran ekspositori. Kesimpulan ini didukung oleh perolehan statistik deskriptif yang menunjukkan rerata kemampuan berpikir kreatif matematik siswa yang menggunakan strategi pembelajaran inkuiri sebesar 86,1. Sementara rerata kemampuan berpikir kreatif matematis siswa yang menggunakan strategi pembelajaran ekspositori sebesar 80,5.Pengaruh strategi pembelajaran dan minat belajar diketahui bahwa nilai sig 0,036 $(<0,05)$,

Menurut sintesis teori yang ada di Bab II, strategi pembelajaran adalah rencana dan cara-cara membawakan pengajaran agar segala prinsip dasar dapat terlaksana dan segala tujuan pengajaran dapat dicapai secara efektif. Strategi pembelajaran yang dipilih oleh guru akan berpengaruh besar terhadap tingkat ketercapaian tujuan pembelajarandalam hal ini kemampuan berpikir kreatif matematik siswa.Pemilihan strategipembelajaran yang tepat akan memotivasi siswa untuk gairah dalam belajar, sehingga siswa dapat melakukan yang dapat menciptakan kemampuan keatifitas. Strategi pembelajaran yang baik adalah bagaimana siswa memahami dan mengajak siswa untuk berpikir kreatif.

Minat belajar adalah sesuatu rasa ketertarikan pada suatu hal atau aktifitas belajar seseorang. Minat pada dasarnya adalah penerimaan akan sesuatu hubungan antara diri sendiri dengan sesuatu di luar diri. Semakin kuat atau dekat hubungan tersebut, semakin besar minatnya.Secara operasional minat belajar adalah sesuatu rasa ketertarikan pada suatu hal atau aktifitas belajar seorang siswa yang secara langsung mempengaruhi prilaku belajar siswa. Minat belajar siswa dapat di lihat dari skor perolehan terhadap angket dalam bentuk skala likert yang diperoleh dengan menggunakan kuisioner yang meliputi indikator sebagai berikut: (1) Perasaan senang siswa dalam memberikan perhatian terhadap pelajaran matematika. (2) Ketekunan dalam mempelajari mata pelajaran matematika. (3) Kebebasan untuk memilih mata pelajaran matematika atas dasar keuntungan dan manfaat. (4) Kecenderungan untuk berusaha aktif untuk meraih manfaat yang diharapkan. (5) Memiliki keterampilan kemampuan dalam mata pelajaran matematika.Tercapainya tujuan kegiatan proses pembelajaran faktor minat belajar yang tinggi sangat diperlukan., semakin tinggi keinginan untuk mencapai tujuan akan semakin kuat pulan minat yang mendorong.Sesuai dengan kondisi tersebut kiranya guru dan orang tua memberi harapan pada anak dalam membangun cita-cita yang mampu mendukung lahirnya minat belajar. 
Dari informasi kuantitatif dan teori tersebut dapat disimpulkan bahwa terdapat pengaruh interaksi yang tidak signifikan penggunaan strategi pembelajaran dan minat belajar terhadap kemampuan berpikir kreatifmatematiksiswa SMP Negeri di kota Depok.

\section{PENUTUP}

\section{Simpulan}

Setelah diadakan penelitian dan analisis data tentang "Pengaruh Strategi Pembelajaran dan Minat Belajar terhaadap Kemampuan Berpikir Kreatif Matematik Siswa" dapat disimpulkan:

1. Terdapat pengaruh yang signifikan strategi pembelajaran terhadap kemampuan berpikir kreatifmatematis siswa. Hal ini dibuktikan dengan nilai $F$-hitung sebesar 13,626 dan sig. $0,01<0,05$. Siswa yang diberi strategi pembelajaran inkuiri memiliki rerata skor kemampuan berpikir kreatif matematik sebesar 86,1 dan rerata skor kemampuan berpikir kreatif matematik yang diberi strategi pembelajaran ekspositori sebesar 80,5.

2. Terdapat pengaruh yang signifikan minat belajar terhadap kemampuan berpikir kreatifmatematis siswa. Hal ini dibuktikan dengan nilai $F$-hitung sebesar 15,992 dan sig. $0,00<0,05$. Siswa dengan minat belajar tinggi memiliki rerata skor kemampuan berpikir kreatif matematik sebesar 86,3 dan rerata skor kemampuan berpikir kreatif matematik siswa dengan minat belajar rendah sebesar 80,2

3. Terdapat interaksi yang signifikan strategi pembelajaran dan minat belajar terhadap kemampuan berpikir kreatifmatematik siswa pada mata pelajaran matematika. Hal tersebut dibuktikan dengan nilai sig $=0,036<0,05$ pada harga $F$-hitung interaksi 0,036 pada taraf signifikansi $5 \%$. Berdasarkan data di atas dapat disimpulkan bahwa terdapat pengaruh yang signifikan interaksi strategi pembelajaran dan minat belajar terhadap kemampuan berpikir kreatifmatematik siswa.

\section{Saran}

1. Mengingat masih banyak hal yang harus diperbaiki dalam meningkatkan kemampuan berpikir kreatif matematis siswa pada mata pelajaran matematika, maka diperlukan upaya perubahan dalam menerapkan strategi pembelajaran yang disesuaikan dengan minat belajar siswa sehingga dapat meningkatkan hasil belajarnya.

2. Strategi pembelajaran merupakan suatu komponen yang dapat mempengaruhi kemampuan berpikir kreatif matematis siswa. Oleh karena itu, sebaiknya guru dapat memetakan minat belajar siswanya untuk selanjutnya dapat menentukan menggunakan strategi pembelajaran sesuai dengan minat belajar siswanya.

3. Agar memperoleh hasil yang komprehensif mengenai mata pelajaran lain, strategi pembelajaran, dan minat belajar disarankan untuk melakukan penelitian lebih lanjut.

\section{DAFTAR PUSTAKA}

Arikunto, S. 2002. Prosedur Penelitian Suatu Pendekatan Praktek. Jakarta: PT. Rineka Cipta.

Avianti, N. 2009. Mudah Belajar Matematika untuk Kelas VIII. Bandung: Dinas Pendidikan Provinsi Jawa Barat.

Nasution, S. 2008. Berbagai Pendekatan dalam Proses Belajar \& Mengajar. Jakarta: PT. Bumi Aksara.

Sagala, S. 2006. Konsep dan Makna Pembelajaran.Bandung: Alfabeta.

Sanjaya, W. 2011. Kurikulum dan Pembelajaran. Jakarta: Kencana Persada Media Group. 
Santoso, S. 2012. Panduan Lengkap SPSS versi 21. Jakarta: PT. Elex Media Komputindo.

Sardiman, A. M. 2004. Interaksi dan Motivasi Belajar Mengajar. Jakarta: PT. Raja Grafindo Persada.

Slameto. 2013. Belajar dan Faktor-faktor yang Mempengaruhinya. Jakarta: Rineka Cipta.

Sudjana, N. 2009. Penilaian Hasil Proses Belajar Mengajar. Bandung: PT. Remaja Rosdakarya.

Suprapto, A. 2007. Psikologi Pembelajaran. Jakarta: Gramedia Widiasarana Indonesia.

Suprihatin. 2013. Pengaruh Model Pembelajaran dan Minat Belajar terhadap Kemampuan Pemahaman Matematika dan Berpikir Kreatif Matematika Siswa. Jakarta: Pasca Sarjana Unindra.

Surya, H. 2011. Strategi Jitu mencapai Kesuksesan Belajar. Jakarta: PT. Elex Media Komputindo.

Suryabrata, S. 1989. Psikologi Pendidikan. Jakarta: CV. Rajawali.

Syah, M. 2010. Psikologi Belajar. Jakarta: Logos Wacana Ilmu.

Tinik, S. 2011. Pengaruh Model Tugas dan Minat Belajar terhadap Hasil Belajar Matematika. Jakarta: Pasca Sarjana Unindra

U. S., Supardi. 2013. Aplikasi Statistik dalam Penelitian. Jakarta: PT. Prima Ufuk Semesta.

Uno, B. H. 2014. Variabel Penelitian dalam Pendidikan dan Pembelajaran. Jakarta: PT. Ina Publikatama. 